\title{
Phylogenetic Relationship Within Genus Araucaria (Araucariaceae) Assessed by Means of AFLP Fingerprints
}

\author{
By V. M. Stefenon ${ }^{1)}$, O. Gailing and R. Finkeldey \\ Institute of Forest Genetics and Forest Tree Breeding, Georg-August-University Göttingen, \\ Büsgenweg 2, 37077 Göttingen, Germany
}

(Received 27 $7^{\text {th }}$ May 2005)

\begin{abstract}
Highly polymorphic AFLP markers were applied to analyse the phylogenetic relationships of seven species from three sections within genus Araucaria (Araucariaceae) with cladistic and phenetic approaches. The objectives of the study were to compare the intrageneric relationships within Araucaria assessed by AFLP markers with the classification according to chloroplast DNA sequences and morphological characters. The AMOVA revealed $48 \%$ of the variation among species. The results of the principal coordinate analysis revealed three distinct groups: (1) A. angustifolia and A. araucana (= section Araucaria), (2) A. bidwillii (= section Bunya) and (3) A. cunninghamii, A. heterophylla, A. rulei and $A$. scopulorum (= section Eutacta). In the cladistic and phenetic analyses, phylogenetic trees were subdivided into two sister clades, one comprising the samples from section Eutacta, the other one was divided again into two sister clades corresponding to sections Araucaria and Bunya. These results are congruent with a previous phylogenetic study of the family Araucariaceae based on $r b c L$ sequences and with the classification of genus Araucaria based on morphological characters. Both $r b c L$ sequence data and AFLP analyses do not support section Bunya as one of the oldest sections within genus Araucaria, as suggested by the fossil record. The utility of AFLP markers for phylogenetic analyses is discussed.
\end{abstract}

Key words: Araucaria, AFLP, phylogeny, phylogenetic relationships.

\section{Introduction}

The genus Araucaria de Jussieu (Family Araucariaceae, Order Coniferales) includes 19 species. Its current geographic distribution is restricted to the Southern hemisphere (GoLTE, 1993). Despite their important ecological and economical role, some species like the South American A. angustifolia (Bert.) O. Ktze and A. araucana (Mol.) K. Koch are nowadays classified as vulnerable due to intense human pressures (BEKESSY et $a l ., 2002$; STEFENON and NODARI, 2003).

From an origin in the Triassic, the family Araucariaceae expanded and diversified in both hemispheres in the Jurassic and Early Cretaceous (Kershaw and WAGSTAFF, 2001). Within genus Araucaria, the fossil records suggest a basal position of section Bunya as one of the oldest recorded sections (STOCKEY and TAYLOR, 1978).

\footnotetext{
1) Corresponding author: Büsgenweg 2, 37077 Göttingen, Germany. Phone: ++ 49-551-39-3534. Fax: ++ 49-551-39-3367. E-mail: gene_mol@yahoo.com.br
}

A phylogenetic study of the $r b c L$ gene for the family Araucariaceae (SETOGUCHI et al., 1998) revealed a clear structure within the genus Araucaria. This structure is in accordance with the taxonomic classification based on morphological characters in sections Araucaria, Eutacta, Intermedia and Bunya. However, molecular data of the $r b c L$ gene did not support the early divergence of the monotypic section Bunya (SETOGUCHi et al., 1998). These authors suggested that further molecular data should be added to enhance the statistical probability concerning the position of $A$. bidwillii Hook. (the only extant species in section Bunya) in the phylogenetic tree. The $r b c L$ sequence is very commonly used for phylogenetic analyses. However, some studies have shown that its sequence is much conserved and sometimes not able to clarify relationships between closely related taxa (WANG et al., 1999; RYDIN and WISTRÖM, 2002). According to WANG et al. (1999), rbcL tends to be conservative among some genera of the gymnosperm family Pinaceae.

AFLPs are highly polymorphic dominant markers that cover a larger proportion of the whole genome (MUELLER and WOLFENBARGER, 1999), randomly accessing both coding (rather conservative) and non-coding (not necessarily conservative) regions. Thus, they may provide many informative markers to complement the single gene $r b c L$ information within genus Araucaria. The AFLP technique has been used to reveal evolutionary relationships at the species or genus level (KoOPMAN et al., 2001; BEARDSLey et al., 2003; BROUAT et al., 2004) and is considered to be able to resolve phylogenetic relationships congruent with analyses based on morphological characters and on nuclear markers as internal transcribed spacers (ITS) or restriction fragment length polymorphisms (RFLPs) (BROUAT et al., 2004). Here, we report a phylogenetic analysis of the genus Araucaria generated by means of AFLP markers and discuss the capacity of these markers to produce informative phylogenetic data to an 'ancient' genus of gymnosperms.

\section{Material and Methods}

\section{Plant material}

Plant material was collected from botanical and private gardens (see Table 1). Seven species of genus Araucaria (A. angustifolia (Bert.) O. Ktze., A. araucana K. Koch, A. bidwillii Hook., A. cunninghamii Aiton ex D. Don., A. heterophylla (Salisb.) Franco, A. rulei F. Muell. and A. scopulorum de Laub.) corresponding to three sections (Araucaria, Bunya and Eutacta) were investigated. Agathis robusta (F. Muell.) F. M. Bailey 
(Araucariaceae) was used as an outgroup (see Table 1). Species identification of the samples was performed in the respective botanical gardens, with exception of sample 'ang5' (cultivated in a private garden in Brazil) that was identified by V. M. STEFEnon. Identification of the samples was confirmed in our laboratory and doubtful samples were excluded from the analysis. Voucher specimens were deposited in the Institute of Forest Genetics and Forest Tree Breeding of the Georg-August-University Göttingen. The natural distribution of the species is shown in Figure 1.

\section{DNA isolation and AFLP analysis}

About fifty milligrams of plant material were disrupted in a 96-well block and the total DNA was extracted using the DNEasy 96 Plant Kit (Qiagen), following the instructions of the manufacturer. The AFLP reactions were performed as described by Vos et al. (1995), with slight modifications as described by GAILING and vON WUEHLISCH (2004). About 150 ng of genomic DNA was incubated at room temperature for about 16 hours for the digestion with the restriction enzymes EcoRI and $M s e I$ and the ligation of the corresponding EcoRI- and $M s e I$-adapters to the ends of the restriction fragments. A pre-selective amplification was performed with the primer pairs displaying one selective nucleotide, namely Eco-primer + A (E-A) and Mse-primer + G (M-G). The PCR protocol for the pre-selective amplification consisted of an initial step at $72^{\circ} \mathrm{C}$ for 2 min followed by 20 cycles at $94^{\circ} \mathrm{C}$ for $10 \mathrm{~s}$, at $56^{\circ} \mathrm{C}$ for $30 \mathrm{~s}$, at $72^{\circ} \mathrm{C}$ for 2 min and of a final extension step at $60^{\circ} \mathrm{C}$ for $30 \mathrm{~min}$. Four microliters of the diluted (1:10) pre-selective reaction were used as template for the selective amplification with the following primer combinations: E-AGA/M-GGA, E-AGA/M-GGG, E-AGC/M-GCC and E-AGC/M-GGA. The PCR protocol for the selective reaction was: a $2 \mathrm{~min}$

Table 1. - Plant material sampled for the phylogenetic analysis and names applied.

\begin{tabular}{|c|c|c|}
\hline Species (Section) & Sample name & Source \\
\hline \multicolumn{3}{|c|}{ A. angustifolia (Araucaria) } \\
\hline & ang1 & University of Freiburg - Germany \\
\hline & ang2 & University of Tübingen - Germany \\
\hline & ang3 & University of Gießen - Germany \\
\hline & ang4 & University of Oldenburg - Germany \\
\hline & ang5 & Cultivated in Private Garden - Lages - Brazil \\
\hline \multicolumn{3}{|l|}{ A. araucana (Araucaria) } \\
\hline & ara1 & University of Gießen - Germany \\
\hline & ara2 & University of Tübingen - Germany \\
\hline & ara3 & University of Oldenburg - Germany \\
\hline & ara4 & Free University of Berlin - Germany \\
\hline & ara5 & University of Göttingen - Germany \\
\hline \multicolumn{3}{|l|}{ A.bidwillii (Bunya) } \\
\hline & bid 1 & University of Freiburg - Germany \\
\hline & bid2 & University of Gießen - Germany \\
\hline & bid3 & University of Tübingen - Germany \\
\hline \multicolumn{3}{|c|}{ A. heterophylla (Eutacta) } \\
\hline & het1 & University of Freiburg - Germany \\
\hline & het2 & University of Gießen - Germany \\
\hline & het3 & University of Oldenburg - Germany \\
\hline \multicolumn{3}{|c|}{ A. cunninghamii (Eutacta) } \\
\hline & cun 1 & University of Tübingen - Germany \\
\hline & cun2 & University of Göttingen - Germany \\
\hline \multicolumn{3}{|l|}{ A. scopulorum (Eutacta) } \\
\hline & sco & University of Tübingen - Germany \\
\hline \multicolumn{3}{|l|}{ A. rulei (Eutacta) } \\
\hline & rul & University of Tübingen - Germany \\
\hline \multicolumn{3}{|c|}{ Agathis robusta (outgroup) } \\
\hline & Agathis & University of Göttingen - Germany \\
\hline
\end{tabular}




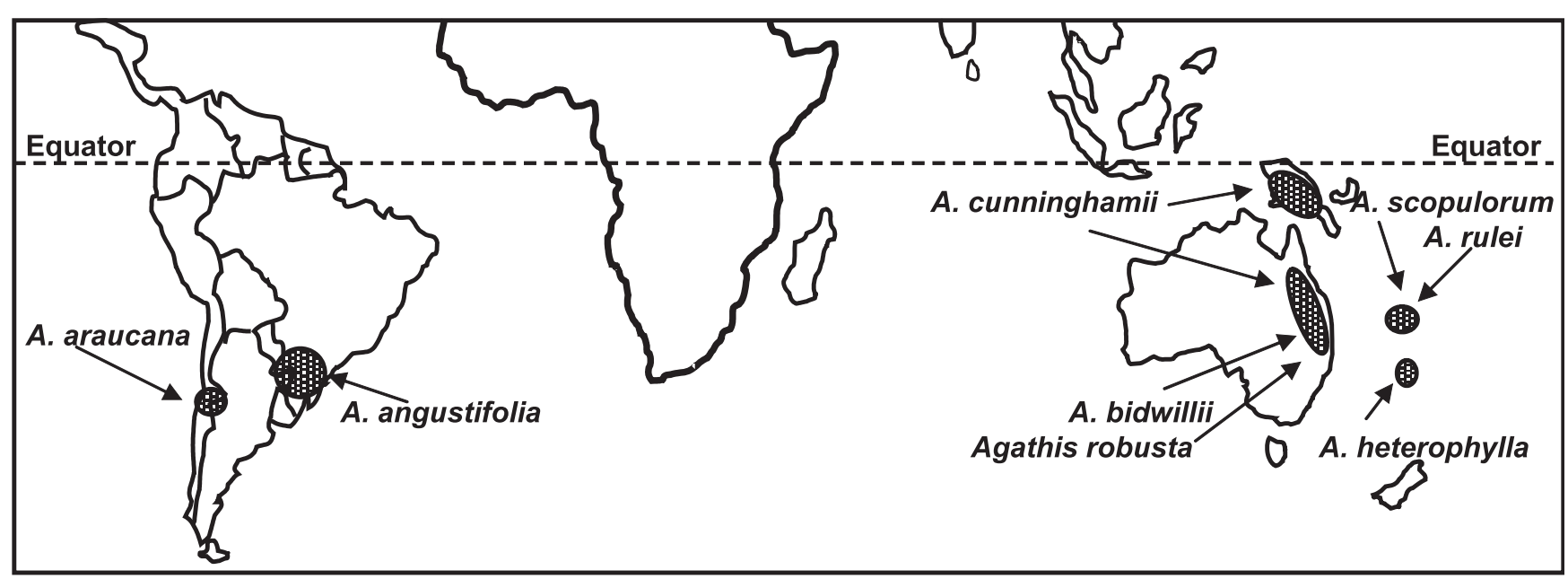

Figure 1. - Natural geographical distribution of Araucaria species analysed and of the outgroup species Agathis robusta. A. angustifolia (Brazil, Argentina and Paraguay), A. araucana (Chile and Argentina), A. bidwillii (Australia), A. cunninghamii (Australia and New Guinea), A. heterophylla (Norfolk Island), A. rulei (New Caledonia), A. scopulorum (New Caledonia) and Agathis robusta (Australia). After Setoguchi et al. (1998) and Golte (1993).

denaturation at $94^{\circ} \mathrm{C}, 9$ cycles at $94^{\circ} \mathrm{C}$ for $10 \mathrm{~s}$, an annealing step at $65^{\circ} \mathrm{C}$ for $30 \mathrm{~s}$ (which was decreased by $1^{\circ} \mathrm{C}$ every cycle until $56^{\circ} \mathrm{C}$ was reached) and an extension step at $72^{\circ} \mathrm{C}$ for $2 \mathrm{~min}$. The reaction was continued with an annealing temperature of $56^{\circ} \mathrm{C}$ for the last 24 cycles ending with a final extension step at $60^{\circ} \mathrm{C}$ for 30 min. All PCR reactions were carried out in a Peltier Thermal Cycler PTC-200 (MJ Research). The EcoRI selective primers were labelled with the fluorescent dyes NED or HEX. The fragments were separated on an ABI Genetic Analyser 3100 with the internal size standard GS 500 ROX (Applied Biosystems). The data were analysed using GeneScan $3.7^{\circledR}$ and Genotyper $3.7^{\circledR}$ software (Applied Biosystems). Bands between 50 and 350 bp (>50 rescaled peak height) were analysed. Absence $(0)$ and presence (1) of fragments was scored and transformed into a binary matrix for data analysis. After confirming that the analysed species were monophyletic, the pre-amplified DNA of up to five samples of each species (see Table 1) was bulked and this bulked DNA served as template for a selective AFLP amplification using the same selective primer pairs and analysis parameters (see above).

\section{Data analysis}

Initially, genetic relatedness of species and sections were assessed for the data set of all individuals using an analysis of molecular variance (procedure AMOVA from Arlequin 2.0; SCHNEIDER et al., 2000) and a principal coordinate analysis (PCO) based on Dice's coefficient of similarity (DICE, 1945) using the procedures SIMQUAL, DCENTER and EIGEN from NTSYSpc 2.0 (ROHLF, 1998). In addition, the data set of all individuals and the data set of bulked DNA were analysed with phenetic (Neighbor-Joining; NJ) and cladistic (Maximun Parsimony; MP) approaches using the software PAUP* version 4.0b10 (SwOFFORD, 1998). The NJ analysis was performed using the genetic distance of Nei and Li (NEI and LI, 1979), which is the complement of Dice's coefficient of similarity, equalling 1 - "Dice". The parsimony heuristic tree searches were carried out under equal weight criterion, the tree bisection-reconnection (TBR) branch swapping algorithm and the option to collapse branches at zero length. A bootstrap analysis (FELSENSTEIN, 1985) with 1000 replicates was conducted to assess the internal support for taxa in NJ and MP analyses.

The NJ and MP trees generated with the data set of all individuals were visually compared to assess the congruence between both analyses (see Figure 3). Additionally, the topology of the MP tree derived from bulked DNA samples was compared with the MP tree calculated from $r b c L$ sequences after SETOGUCH et al. (1998), in order to assess the congruence between AFLP and cpDNA analyses (see Figure 4).

\section{Results and Discussion}

\section{Relationship among species}

Following the parameters applied for markers selection, the four primer combinations generated a total of 678 polymorphic markers. From 136 to 210 markers could be analysed per primer combination (mean number $=169.5$ markers).

The partitioning of the molecular variance (AMOVA) among species was calculated for the data set of all individuals and revealed that $48 \%$ of the variation reside among species $\left(\Phi_{\mathrm{ST}}=0.48 ; \mathrm{p}<0.001\right)$.

The PCO analysis generated three groups that were clearly differentiated and corresponded to sections Araucaria, Bunya and Eutacta. The first principal coordinate explained $23 \%$ and the second principal coordinate explained $13 \%$ of the total variation. The three represented sections were clearly differentiated. Samples of A. angustifolia and A. araucana (Section Araucaria) group together, while the monotypic section Bunya, represented by $A$. bidwillii, is also clearly separated in this analysis. The structure among species within section Eutacta was not clarified, but the four species analysed of this section form a distinct group (Figure 2).

For the data set with all individuals, ninety percent (608 out of 678 ) of the AFLP markers were parsimony- 


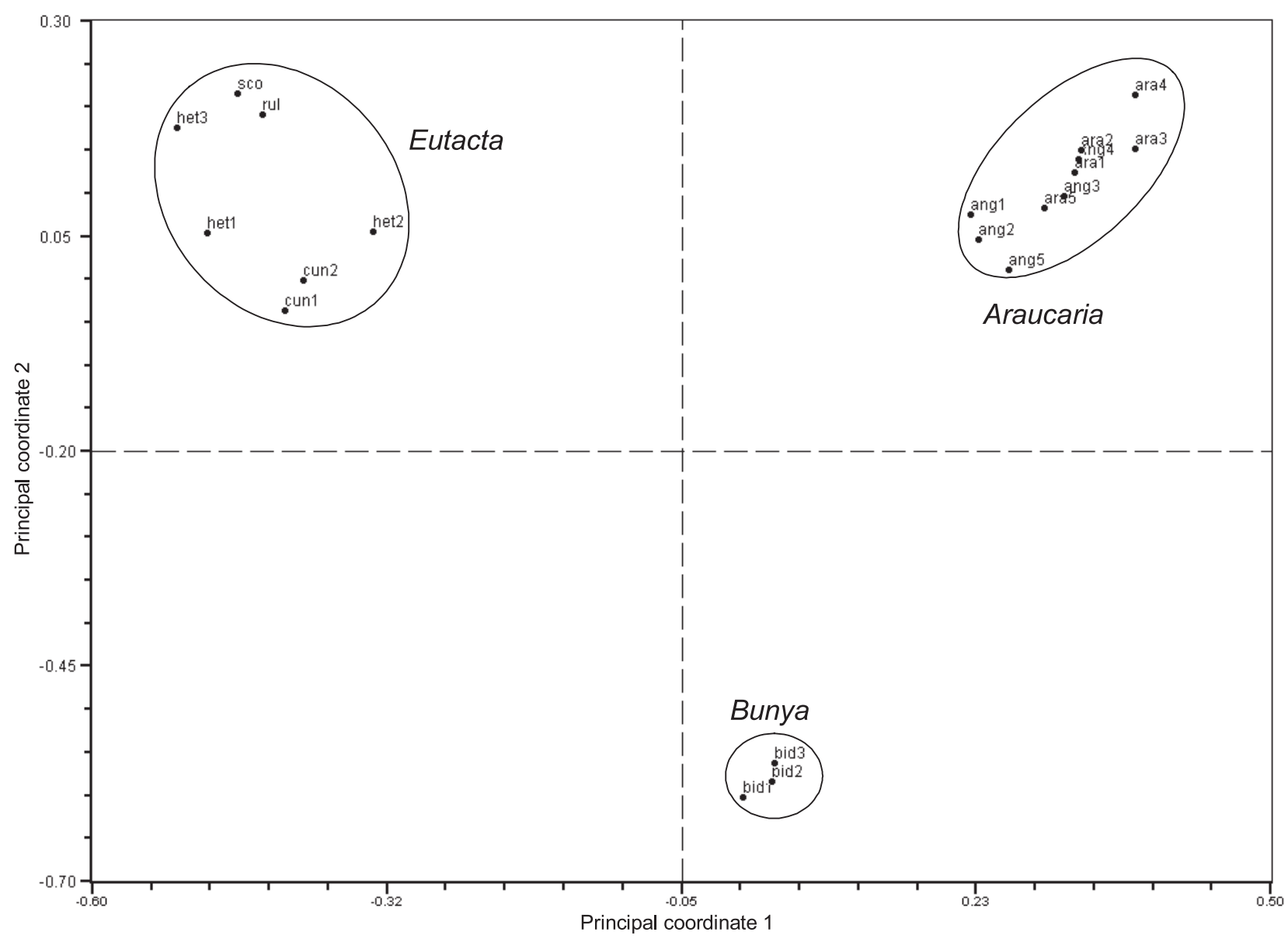

Figure 2. - Principal coordinate analyses (PCO) based on Dice's coefficient of similarity (DiCE, 1945) showing differentiation among sections of genus Araucaria. The first coordinate describes $23 \%$ and the second coordinate $13 \%$ of the total variation. For sample codes see Table 1 .

Table 2. - Pairwise genetic distances (NEI and LI, 1979) between samples of Araucaria. For sample codes see Table 1.

\begin{tabular}{|c|c|c|c|c|c|c|c|c|c|c|c|c|c|c|c|c|c|c|c|c|c|}
\hline & 1 & 2 & 3 & 4 & 5 & 6 & 7 & 8 & 9 & 10 & 11 & 12 & 13 & 14 & 15 & 16 & 17 & 18 & 19 & 20 & 21 \\
\hline 1 ang1 & - & & & & & & & & & & & & & & & & & & & & \\
\hline 2 ang2 & 0.099 & - & & & & & & & & & & & & & & & & & & & \\
\hline 3 ang3 & 0.085 & 0.073 & - & & & & & & & & & & & & & & & & & & \\
\hline 4 ang 4 & 0.055 & 0.069 & 0.048 & - & & & & & & & & & & & & & & & & & \\
\hline 5 ang 5 & 0.080 & 0.035 & 0.070 & 0.058 & - & & & & & & & & & & & & & & & & \\
\hline 6 ara 1 & 0.128 & 0.081 & 0.102 & 0.115 & 0.077 & - & & & & & & & & & & & & & & & \\
\hline 7 ara 2 & 0.130 & 0.095 & 0.101 & 0.111 & 0.099 & 0.055 & - & & & & & & & & & & & & & & \\
\hline 8 ara3 & 0.125 & 0.093 & 0.082 & 0.097 & 0.091 & 0.058 & 0.052 & - & & & & & & & & & & & & & \\
\hline 9 ara 4 & 0.123 & 0.123 & 0.086 & 0.089 & 0.123 & 0.097 & 0.073 & 0.080 & - & & & & & & & & & & & & \\
\hline 10 ara5 & 0.122 & 0.060 & 0.095 & 0.101 & 0.073 & 0.039 & 0.061 & 0.060 & 0.105 & - & & & & & & & & & & & \\
\hline 11 het 1 & 0.174 & 0.139 & 0.158 & 0.163 & 0.149 & 0.157 & 0.167 & 0.174 & 0.190 & 0.143 & - & & & & & & & & & & \\
\hline 12 het 2 & 0.142 & 0.124 & 0.149 & 0.150 & 0.131 & 0.130 & 0.156 & 0.153 & 0.177 & 0.129 & 0.039 & - & & & & & & & & & \\
\hline 13 het 3 & 0.177 & 0.143 & 0.158 & 0.165 & 0.152 & 0.153 & 0.172 & 0.164 & 0.197 & 0.137 & 0.019 & 0.042 & - & & & & & & & & \\
\hline 14 cun 1 & 0.164 & 0.162 & 0.186 & 0.189 & 0.159 & 0.190 & 0.197 & 0.195 & 0.229 & 0.172 & 0.117 & 0.110 & 0.117 & - & & & & & & & \\
\hline 15 cun 2 & 0.165 & 0.150 & 0.175 & 0.178 & 0.152 & 0.163 & 0.174 & 0.187 & 0.220 & 0.154 & 0.095 & 0.092 & 0.102 & 0.053 & - & & & & & & \\
\hline $16 \mathrm{rul}$ & 0.218 & 0.158 & 0.178 & 0.185 & 0.167 & 0.194 & 0.190 & 0.196 & 0.212 & 0.181 & 0.094 & 0.121 & 0.095 & 0.155 & 0.141 & - & & & & & \\
\hline 17 bidl & 0.142 & 0.119 & 0.129 & 0.146 & 0.112 & 0.149 & 0.145 & 0.144 & 0.172 & 0.122 & 0.145 & 0.142 & 0.158 & 0.150 & 0.152 & 0.195 & - & & & & \\
\hline 18 bid 2 & 0.158 & 0.116 & 0.139 & 0.145 & 0.113 & 0.127 & 0.132 & 0.126 & 0.171 & 0.119 & 0.148 & 0.142 & 0.153 & 0.160 & 0.161 & 0.186 & 0.048 & - & & & \\
\hline $19 \mathrm{bid} 3$ & 0.162 & 0.120 & 0.130 & 0.152 & 0.116 & 0.126 & 0.138 & 0.126 & 0.159 & 0.116 & 0.153 & 0.145 & 0.164 & 0.177 & 0.168 & 0.190 & 0.054 & 0.050 & - & & \\
\hline $20 \mathrm{sco}$ & 0.203 & 0.164 & 0.181 & 0.193 & 0.174 & 0.184 & 0.171 & 0.177 & 0.195 & 0.167 & 0.089 & 0.106 & 0.086 & 0.132 & 0.129 & 0.081 & 0.192 & 0.194 & 0.179 & - & \\
\hline 21 Agathis & 0.228 & 0.180 & 0.219 & 0.223 & 0.169 & 0.191 & 0.210 & 0.224 & 0.326 & 0.168 & 0.216 & 0.195 & 0.218 & 0.204 & 0.197 & 0.261 & 0.192 & 0.194 & 0.200 & 0.234 & - \\
\hline
\end{tabular}


informative, while the NJ tree was generated with all 678 markers. Pairwise genetic distances (NEI and LI, 1979) between samples are shown in Table 2. In the MP analysis heuristic search yielded two shortest trees of 2003 steps, a consistency index (CI) of 0.31 and a retention index (RI) of 0.53 . The consistency index in the parsimony analysis suggests a high level of homoplasy. Nevertheless all sections and species were supported by high bootstrap values (Figure 3). Araucaria rulei and A. scopulorum (section Eutacta) that are represented only by unique samples cluster together in clade Eutac$t a$ and show the same position in $r b c L$ and AFLP trees (Figure 4) suggesting that also unique samples are informative to represent the respective species.

Comparing cladistic and phenetic analyses no difference was observed in the general topology of the generated trees (see Figure 3). The monotypic section Bunya revealed to be sister group to section Araucaria and the Eutacta clade is sister to the Araucaria/Bunya clade. Thus, the basal position of Bunya as one of the oldest recorded sections, as indicated by the fossil record (STOCKEY and TAYLOR, 1978), is not supported by our analysis. Congruence with $r b c L$ data (SETOGUCHI et al., 1998) and more recent paleobotanical evidence
(STOCKEY, 1994) suggest that many fossils formerly named as Bunya should be re-evaluated.

According to the NJ tree A. cunninghamii is sister to the other species of section Eutacta. A. heterophylla forms a well supported sister clade to $A$. rulei and A. scopulorum. In the MP tree these species form a polytomy. The clade comprising $A$. heterophylla and A. cunninghamii as sister species has only $50 \%$ bootstrap support.

Phylogenetic trees calculated for individual samples (Figure 3) and from bulked DNA (Figure 4) show the same topology and are congruent with the $r b c L$ Maximum Parsimony analysis from SeTOGUCHI et al. (1998). Figure 4 shows a comparison between the AFLP phylogram generated from bulked DNA (678 AFLP markers, 430 parsimony-informative markers, tree length $=1152$ steps, $\mathrm{CI}=0.48, \mathrm{RI}=0.36$ ) and the $r b c L$ phylogeny.

Section Araucaria (A. angustifolia and A. araucana) and the monotypic section Bunya (A. bidwillii) that group together in the AFLP tree also share important taxonomic characters. Both sections are characterized by large and flat leaves, hypogeal germination, fleshy seedlings and two cotyledons that are long-stalked dur-
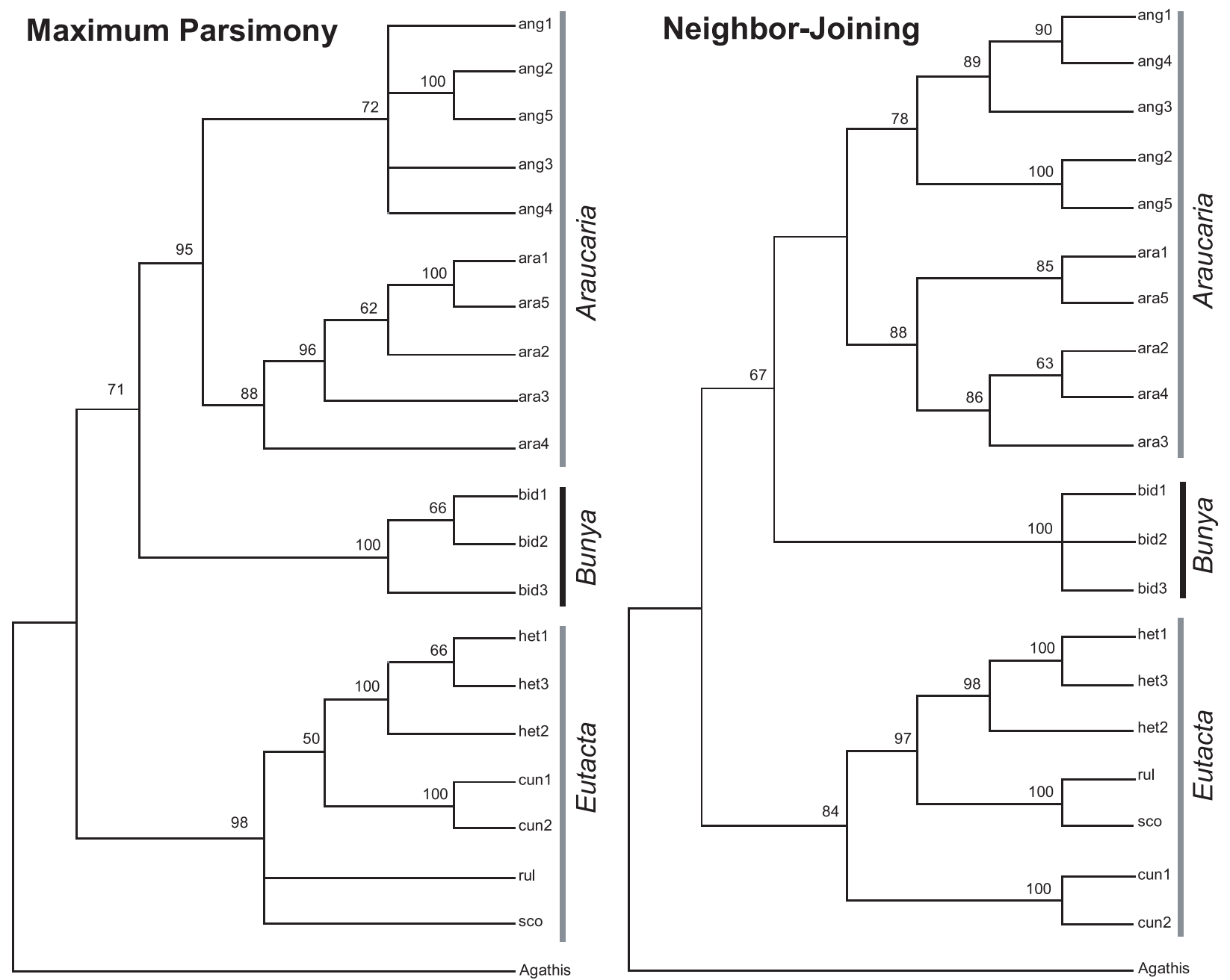

Figure 3. - Parsimony and Neighbor-Joining (Nei and Li's genetic distance; NEI and LI, 1979) phylogenetic trees generated with 678 AFLP markers for individuals of seven species of Araucaria from South America (A. angustifolia and A. araucana) and Australasia (A. cunninghamii, A. heterophylla, A. rulei, A. scopulorum and A. bidwillii). Bootstrap values for 1000 replicates are shown for each node. For sample codes see Table 1. 


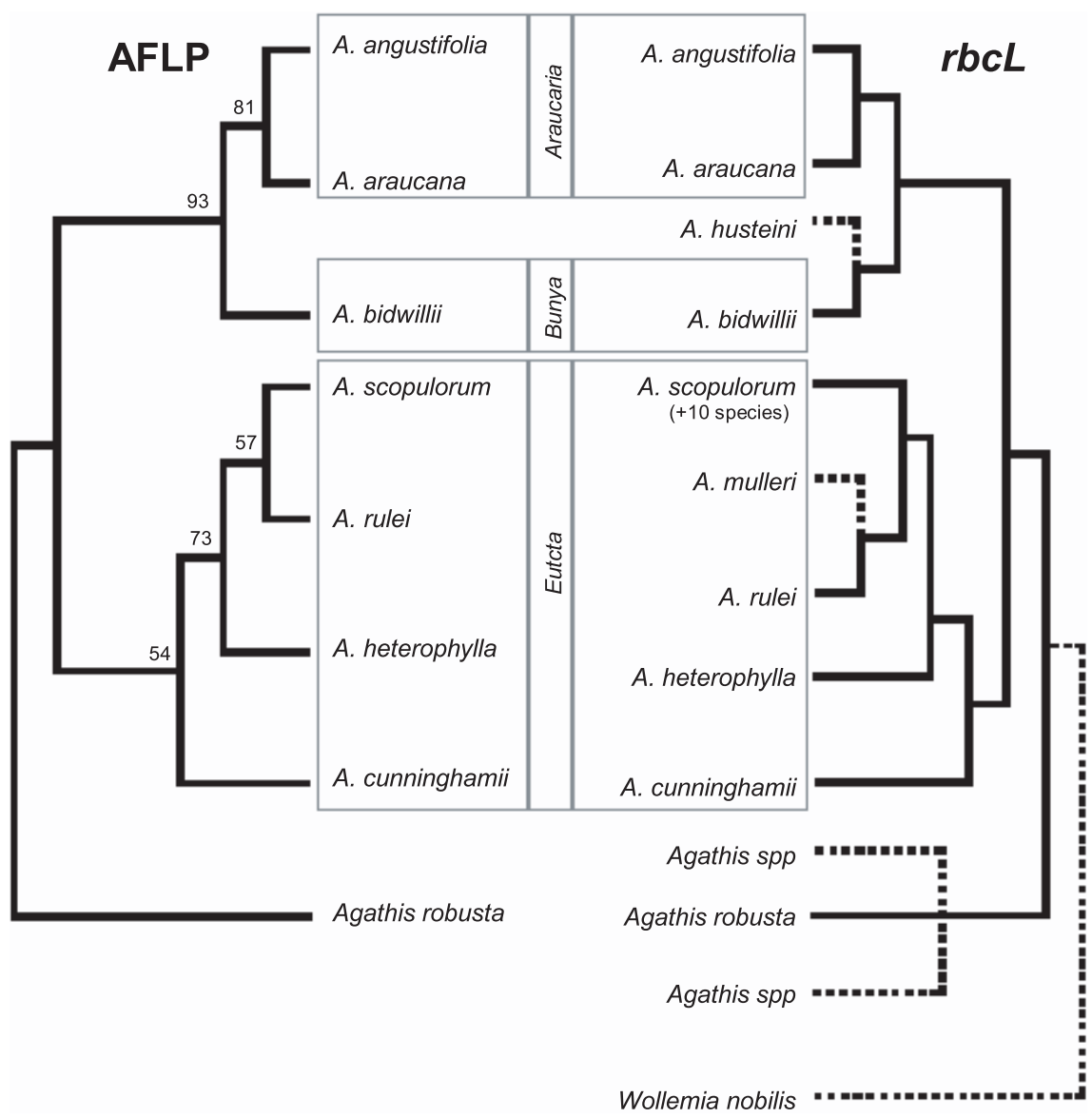

Figure 4. - Comparison between AFLP (bulked DNA) and $r b c L$ gene sequences Maximum-Parsimony phylogenies of Araucaria. Numbers at each node in the AFLP tree represent bootstrap values (1000 replicates). Doted branches in the $r b c L$ tree show species not included in the present AFLP study. The $r b c L$ phylogenetic tree is adapted from SETOGUCHI et al. (1998).

ing germination and retained in seed coats (STOCKEY, 1982; GolTe, 1993). Species from section Eutacta display smaller leaves, epigeal germination, four sub-sessile cotyledons that are freed from seed walls at germination and no fleshy seedlings (STOCKeY, 1982; GolTe, 1993).

Within section Araucaria a considerable differentiation supported by high bootstrap values was observed among individuals within species $A$. angustifolia and A. araucana suggesting that the individuals sampled in Botanical Gardens originated from different geographic locations.

In conclusion, the relationship among species of Araucaria revealed by AFLPs are in accordance with prior classifications based on molecular ( $r b c L$ sequences; SETOGUChi et al., 1998) and morphological (STOCKey, 1982) studies.

\section{Usefulness of AFLP technique}

Despite the wide use of AFLP markers for genetic studies, there are doubts of using this technique to determine phylogenetic relationships. In order to establish phylogenetic relationships among taxa, the character analysed must show homologous similarities (modification by descent). One of the weaknesses of AFLP markers to assess phylogenetic relationships is the fact that fragments of related taxa may have the same length, but a different sequence and are therefore not orthologous. With increasing genetic differentiation among taxa fragments of the same size are more likely to be not orthologous (MECHANDA et al., 2004).

Furthermore, it is known that there are many duplication events during species evolution resulting in paralogs that constitute a general problem in deducing phylogenies. This problem is even more acute, if single genes from a multigene family (and not single copy genes) are analysed.

However, the strongest advantage of AFLP markers to infer phylogenetic relationships is that they sample from many regions of the genome, generating a large number of markers (MUELLER and WOLFENBARGER, 1999; WeISING et al., 2005). These genome-wide data sets may provide high power in testing specific phylogenetic relationships (RoKAs et al., 2003).

If a large nummber of AFLP markers are investigated, many of them are likely to be orthologous. Indeed, ROUPPE VAN DER VOORT et al. (1997) found 19 identical sequences out of 20 putatively homologous AFLP markers sequenced in potato. PARSONS and SHAW (2001) sequenced ten AFLP fragments co-migrating in cricket species (genus Laupala) and found a degree of sequence 
similarity of the same-sized bands between 97 and $100 \%$. They suggested that same-sized AFLP fragments can be confidently considered as homologous. Thus due to the large number of markers analysed any bias in phylogenetic inference are likely to be small and the results will accurately reflect the genetic relationships among taxa (PARSONS and SHAW, 2001).

Since the relative amount of homoplasic AFLP fragments and their effect on reconstructing phylogenetic relationships is difficult to assess, the application of either phenetic or cladistic approaches when using AFLP markers has been discussed (KoOPMAN et al., 2001; LARA-CABRERA and SPOONER, 2004).

KOOPMAN et al. (2001) suggested that, if topologies of the phenogram and the cladogram generated by AFLP fingerprints are identical, homoplasies do not influence the cladistic analysis and will not affect conclusions of species relationships. Besides, in bootstrap or jackknife branch support analyses, the presence of internal conflict caused by homoplasies will lead to an exclusion of these branches as uninformative and they will not affect the conclusions on species relationships (KOOPMAN et al., 2001).

Despite the potential limitations for the use of the AFLP technique in phylogenetic analyses, in particular false fragment homology, congruence has been reported between AFLP and single gene sequence phylogenetic analyses (present study; SPOONER et al., 2005), between AFLP and ITS/ETS phylogenetic analyses (KOOPMAN et al., 2001; BEARDSLey et al., 2003; SPOONER et al., 2005) and between AFLP and morphological characters analyses (present study; SPOONER et al., 2005). Furthermore, analyses of just one or few sequences, as well as analyses of a large number of "biased" genes are likely to produce incorrect phylogenetic trees with even high bootstrap support (RoKAs et al., 2003). Thus, AFLP fingerprints can be a useful technique to complement the information about phylogenetic relationships among related taxa.

Since the present AFLP phylogenetic analysis of genus Araucaria showed high congruence with morphological and cpDNA sequence classifications, AFLP markers can be used to confirm or complement the information about phylogenetic relationships among ancient taxa, especially if DNA sequence variation is limited or sequence information of only few loci is available.

\section{Conclusions}

In the present study, species within genus Araucaria proved to be well separated from each other with strongly supported monophyletic sections. The relationship between the South American species A. angustifolia and A. araucana (section Araucaria) is also clearly resolved. Within section Eutacta from Australasia the species relationships are only resolved in the NJ tree. In addition, our data and previous reports (STEFENON et al., 2003; STEFENON and NoDARI, 2003) suggest that AFLPs provide suitable molecular markers to study the relationships among species within genus Araucaria and also within Araucaria species. In an ongoing project the usefulness of AFLP markers to distinguish A. angustifolia populations from different geographic origins in Brazil will be tested.

\section{Acknowledgments}

We thank Dr. T. SPECK (University of Freiburg), Dr. K. DoBAT (University of Tübingen), H. LAAKE (University of Gießen), A. GERLACH (University of Oldenburg), V. MenG (University of Göttingen) and R. VoGT (Botanic Garden Berlin) for plant material; Mr. T. SELIGER and Mrs. O. ARTES for technical help and two anonymous reviewers for the helpful comments in a previous version of this paper. V. M. STEFENON is $\mathrm{PhD}$ grant holder from CAPES - Brasilia/Brazil.

\section{References}

Beardsley, P. M., A. Yen and R. G. Olmstead (2003): AFLP phylogeny of Mimulus section Erytranthe and the evolution of hummingbird pollination. Evolution 57: 1397-1410.

Bekessy, S. A., T. R. Alnutt, A. C. Premoli, A. Lara, R. A. Ennos, M. A. Burgman, M. Cortes and A. C. NewTON (2002): Genetic variation in the vulnerable and endemic Monkey Puzzle tree, detected using RAPDs. Heredity 88: 243-249.

Brouat, C., D. Mckey and J. P. Douzery (2004): Differentiation in a geographical mosaic of plants coevolving with ants: phylogeny of the Leonardoxa africana complex (Fabaceae: Caesalpinoideae) using amplified fragment length polymorphism markers. Molecular Ecology 13: 1157-1171.

Dice, L. R. (1945): Measures of the amount of ecologic association between species. Ecology 26: 297-302.

FELSENSTEIN, J. (1985): Confidence limits on phylogenies: an approach using bootstrap. Evolution 39: 783-791.

GAILING, O. and G. VON WUEHLISCH (2004): Nuclear markers (AFLP) and chloroplast microsatellites differ between Fagus sylvatica and F. orientalis. Silvae Genetica 53: 105-110.

Golte, W. (1993): Araucaria: Verbreitung und Standortansprüche einer Coniferengattung in vergleichender Sicht. 167 p. Franz Steiner, Stuttgart.

Kershaw, P. and B. Wagstaff (2001): The Southern conifer family Araucariaceae: history, status and value for paleoenvironmental reconstruction. Annual Review of Ecology and Systematics 32: 397-414.

Koopman, W. J. M., M. J. Zevenbergen and R. G. van DEN BERG (2001): Species relationships in Lactuca s.l. (Lactuceae, Asteraceae) inferred from AFLP fingerprints. American Journal of Botany 88: 1881-1887.

LARA-CABRERA, S. I. and D. M. Spooner (2004): Taxonomy of North and Central American diploid wild potato (Solanum sect. Petota) species: AFLP data. Plant Systematics and Evolution 248: 129-142.

Mechanda, S. M., B. R. Baum, D. A. Johnson and J. T. ARNASON (2004): Sequence assessment of comigrating $\mathrm{AFLP}^{\mathrm{TM}}$ bands in Echinacea - implications for comparative biological studies. Genome 47: 15-25.

Mueller, U. G. and L. L. Wolfenbarger (1999): AFLP genotyping and fingerprinting. Trends in Ecology and Evolution 14: 389-394.

NEI, M. and W. LI (1979): Mathematical model for studying genetic variation in terms of restriction endonucleases. Proceedings of the National Academy of Science of the USA 76: 5269-5273. 
Parsons, Y. M. and K. L. Shaw (2001): Species boundaries and genetic diversity among Hawaiian crickets of the genus Laupala identified using amplified fragment length polymorphism. Molecular Ecology 10: 1765-1772.

RoHLF, F. J. (1998): NTSYSpc: Numerical taxonomy and multivariate analysis system ver. 2.0. Departament of Ecology and Evolution, State University of New York, USA.

Rokas, A., B. L. Williams, N. King and S. B. CArroll (2003): Genome-scale approaches to resolving incongruence in molecular phylogenies. Nature 425: 798-804.

ROUPPE VAN DER VOORT, J. N. A. M., P. VAN ZANDVOORT, H. J. van Eck, R. T. Folkertsma, R. C. B. Hutten, J. Draaistra, F. J. Gommers, E. Jacobsen, J. Helder and J. BAKKER (1997): Use of allele specificity of comigrating AFLP markers to align genetic maps from different potato genotypes. Molecular Genetics and Genomics 255: 438-447.

RYDin, C. and N. WiströM (2002): Phylogeny of Isoëtes (Lycopsida): resolving basal relationships using $r b c L$ sequences. Taxon 51: 83-89.

Schneider, S., D. Roessli and L. Excoffier (2000): Arlequin ver. 2.000: A software for population genetics data analysis. Genetics and Biometry Laboratory, University of Geneva, Switzerland.

Setoguchi, H., T. A. Osawa, J.-C. Pintaud, T. Jaffré and J.-M. VeILlon (1998): Phylogenetic relationships within Araucariaceae based on $r b c L$ gene sequences. American Journal of Botany 85: 1507-1516.

SwOFFoRD, D. L. (1998): PAUP*: Phylogenetic analysis using parsimony and other methods. Illinois Natural History Survey, Champaing, IL.
Stefenon, V. M. and R. O. NodARI (2003): Marcadores moleculares no melhoramento genético de araucária. Biotecnologia Ciência e Desenvolvimento 31: 95-99.

Stefenon, V. M., R. O. Nodari and M. S. Reis (2003): Padronização de protocolo AFLP e sua capacidade informativa para análise da diversidade genética em Araucaria angustifolia. Scientia Forestalis 64: 163-171.

Stockey, R. A. and T. N. TAYLOR (1978): On the structure and evolutionary relationships of the Cerro Quadrado fossil conifer seedlings. Botanical Journal of the Linnean Society 76: 161-176.

Stockey, R. A. (1982): The Araucariaceae: an evolutionary perspective. Review of Paleobotany and Palynology 37: 133-154.

Stockey, R. A. (1994): Mesozoic Araucariaceae: morphology and systematics relationships. Journal of Plant Research 107: 493-502.

Vos, P., R. Hogers, M. Bleeker, M. Reijans, T. Lee, M. Hornes, A. FriJters, J. Pot, J. Peleman, M. Kuiper and M. ZABEAU (1995): AFLP: a new technique for DNA fingerprinting. Nucleic Acids Research 23: 4407-4424.

WANG, X.-R., Y. Tsumura, H. Yoshimaru, K. NAGAsaka and A. E. SzimdT (1999): Phylogenetic relationships of Eurasian pines (Pinus, Pinaceae) based on chloroplast rbcL, matK, rpl20-rps18 spacer, and trnV intron sequences. American Journal of Botany 86: 1742-1753.

Weising, K., H. NYBom, K. WolfF and G. KaHL (2005): DNA fingerprinting in plants: principles, methods, and applications. CRC Press, Boca Raton/FL.

\title{
Short Note: Crossability Between Pinus uliginosa and its Putative Parental Species Pinus sylvestris and Pinus mugo
}

\author{
By A. LewANDOWsKi and M. WiśniewsKa
}

Institute of Dendrology, Polish Academy of Sciences, Parkowa 5, 62-035 Kórnik, Poland. Corresponding author: e-mail: alew@rose.man.poznan.pl; tel. +48 061 8170033, fax: +48 0618170166

(Received 19 ${ }^{\text {th }}$ June 2005)

\begin{abstract}
Results of artificial fertilization of $P$. uliginosa with $P$. sylvestris and P. mugo are presented and discussed. $P$. sylvestris and $P$. mugo are thought to be the parental species of $P$. uliginosa. Two grafts of one $P$. uliginosa clone from Arboretum of the Institute of Dendrology in Kórnik, Poland were used as mother individuals. One individual of $P$. sylvestris and one individual of $P$. mugo were the pollen donors. Three mature cones were obtained as the result of artificial pollination of $P$. uliginosa with $P$. mugo pollen. Out of 107 seeds, 68 were filled what gives $63 \%$. P. uliginosa conelets pollinated
\end{abstract}

with $P$. sylvestris pollen were all aborted. Based on obtained data, close phylogenetic relationship between $P$. uliginosa and $P$. mugo complex is suggested.

Key words: P. uliginosa, P. sylvestris, P. mugo, hybridization, pollination, crossability.

\section{Introduction}

Dwarf mountain pine complex (Pinus mugo Turra complex) is well known for its taxonomically perplexing pattern of phylogenetic relations and contradictory views on taxonomic rank of taxons belonging to this 